\title{
Association of chronic pain with structural alteration and central sensitization in Japanese patients with knee osteoarthritis
}

\author{
Takafumi Hattori ${ }^{1,2}$, Kazuhiro Shimo ${ }^{3}$, Yuto Niwa ${ }^{1}$, \\ Yuji Tokiwa ${ }^{1}$, and Takako Matsubara ${ }^{1,3}$ \\ ${ }^{1}$ Kobe Gakuin University Graduate School of Rehabilitation \\ ${ }^{2}$ Department of Rehabilitation, Maehara Orthopedics Rehabilitation Clinic \\ ${ }^{3}$ Department of Rehabilitation, Faculty of Rehabilitation, Kobe Gakuin University
}

\begin{abstract}
Objective: Pain severity is associated with structural joint pathology and pain sensitization in knee osteoarthritis (OA); however, the applicability of these findings to Japanese patients remains unknown. Hence, we investigated the association between either radiologic severity or central sensitization and chronic joint pain in knee OA.

Methods: We divided 43 patients with knee OA into two groups based on the severity of knee joint pain: strong/severe pain (Group A, $n=17$ ) and mild / moderate pain (Group B, n=26). Radiographic evidence of structural joint pathology was graded according to the Kellgren-Lawrence (K-L) scale. The degree of central sensitization was indexed using quantitative sensory testing (QST), including pressure pain threshold (PPT) and temporal summation of pain (TSP). In order to determine the factors that influence joint pain severity, we compared data from the radiographic assessment and QST between the two groups and examined the correlation between pain severity and either radiographic assessment or QST.

Results: There were no significant differences in the K-L scale between patients with either strong/severe or mild / moderate joint pain. Those with strong/severe pain had a lower PPT and higher TSP than did the patients with mild/moderate pain. In addition, QST was found to be significantly correlated with joint pain.

Conclusion: When measured using QST, we found a significant difference in central sensitization between Groups A and B, whereas radiologic severity did not differ significantly.
\end{abstract}

\section{Keywords}

Knee osteoarthritis; Central sensitization; Quantitative sensory testing; Temporal summation of pain; Radiologic structural alteration 


\title{
日本人変形性膝関節症の慢性関節痛と関節変形，中枢感作の関係性
}

\author{
服部 貴文 $1,2 /$ 下和弘 $3 /$ 丹羽 祐斗 $1 /$ 常盤 雄地 $1 /$ 松原貴子 1,3 \\ ${ }^{1}$ 神戸学院大学大学院 総合リハビリテーション学研究科 \\ 2 前原整形外科リハビリテーションクリニック リハビリテーション部 \\ 3 神戸学院大学 総合リハビリテーション学部
}

\section{はじめに}

変形性膝関節症 (knee osteoarthritis: 膝 OA) は高齢者の quality of life の低下を来たす代表的 な疾患であり，本邦の有病率も非常に高い20,23)。 膌 OA の最大の問題は慢性的な関節痛であり, 関節変形が進行するに伴い疼痛が増悪するとさ れる一方，関節変形と疼痛は必ずしも関連しな いとの報告もある ${ }^{5,12)}$ 。本邦の膝 OA において も，関節変形が重度である Kellgren-Lawrence （K-L）分類 3 以上の患者の疼痛保有率が男性 の約 $40 \%$ ，女性の約 $60 \%$ にとどまることが報 告されており 20)，関節変形の程度が著しけれ ば必ずしも疼痛が重篤ではなく，関節変形と疼 痛の程度が乘離する症例も多い。また, 人工膝 関節置換術（total knee arthroplasty：TKA）に よって構造的問題を改善しても疼痛の改善が得 られない症例も存在することから ${ }^{8)}$, 膝 $\mathrm{OA}$ の 疼痛の重篤化には関節変形以外の要因も関与す ることが示唆される。

一方, 膝 OA の慢性関節痛には侵害受容性 疼痛のみならず，中枢感作などの神経機能異常 も関与する場合があることが明らかとなってい る28)。滕 OAにおいて，膝関節からの持続的 な侵害受容入力は中枢感作を惹起し，これが疼 痛の慢性化に関与する26)。この中枢感作の定量 的評価として, 近年, 定量的感覚検査 (quanti- tative sensory testing：QST）が用いられてお り 28), QST の中でも Static QST である圧痛閾 值 (pressure pain threshold: PPT) や Dynamic QST である時間的加重（temporal summation of pain : TSP) については膝 OA の疼痛症状との 関連が報告されている28)。PPT は圧痛計を用 いて圧刺激に対する疼痛閾值を評価し，疼痛部 位の PPT 低下は局所の痛覚感受性が低下する 末梢感作，疼痛部位とは離れた部位においても PPT 低下を認める場合は広範な痛覚過敏を呈す る中枢感作が生じていることを反映する 1,15$) 。$ 一方，TSP は上行性の疼痛伝達系を反映する 評価法であり，繰り返される侵害刺激に対し痛 みが増加する現象を示す。これは, 侵害受容 ニューロン，特に脊髄後角ニューロンのインパ ルス発射増加，つまり中枢感作を定量化するも のであると定義されている5)。しかし，本邦で は膝 OA の中枢感作に関する報告は未だ少な く, QSTを用いて中枢感作の程度やその広が りについて検証した報告はない。また，OAを 対象とした先行研究では, TKAの適応となる ような関節変形が重度の膝 OA のみを対象に 中枢感作を調べた報告が多いため $1,16,30)$ ，関節 変形の程度が軽度から重度まで網羅したすべて のステージにおいて，関節変形と中枢感作のい ずれが膝 OA の慢性関節痛に関与するかにつ いては明らかではない。 
そこで本研究はさまざまな程度の関節変形の 日本人滕 $\mathrm{OA}$ 患者を対象に, 中枢感作の特徵 について QST を用いて定量的に評価するとと もに, 膝 OA の関節変形と中枢感作のいずれ が慢性関節痛により強く影響するのかについて 検討した。

\section{対象と方法}

\section{1. 研究倫理}

本研究は, 前原整形外科リハビリテーション クリニック（番号：前研 19-001）抢よび神戸学 院大学「人を対象とする研究に関する倫理委員 会」(番号: 総論 19-23) の承認を得た上で実施 した。すべての対象者に対して, 研究目的, 方 法, 予想される結果, リスクについて文書によ る説明を行い, 同意を得た上で行った。

\section{2. 対象}

対象は, 前原整形外科リハビリテーションク リニックを外来受診した膝 OA 患者 43 名（男 性 12 名, 女性 31 名, 平均年齢 $68.2 \pm 9.9$ 歳) とした。取込基準は, 膝関節の疼痛が主訴, 疼 痛持続期間が 6 か月以上，片側および両側性で $\mathrm{K}-\mathrm{L}$ 分類 grade 1 以上の関節変形, 40 歳以上 とした。除外基準は全身性炎症性疾患, 検查に 影響を与えるほどの著しい認知機能障害, 腰部 由来の下肢痛を有する, 重度の精神系・心血管 系・呼吸器系・代謝系疾患とした。群分けは, 先行研究 $1,4,17$ ) 参考に, 初診時に 24 時間以内 の最大の疼痛を聴取し, 疼痛が重篤 (numerical rating scale : NRS $\geq 6$ ) である 17 名を Group A, 軽度（NRS<6)である 26 名を Group B とした。 なお, NRSは 0 を「疼痛なし」, 10 を「対象者 が想像しうる耐え難いほどの疼痛」とし，0-10
の 11 段階で評価した。

\section{3. 測定項目}

患者特性として年齢, 性別, 体格指数 (body mass index：BMI), 疼痛持続期間, 膝関節の主 観的疼痛強度 (NRS), 機能障害を評価した。 機能障害は Knee injury and Osteoarthritis Outcome Score (KOOS) の日常生活機能サブス ケールを用いて評価した ${ }^{21,25)}$ 。また, 薬物療法 の処方についても調べた。

関節変形の評価には $\mathrm{K}-\mathrm{L}$ 分類を用いた。 $\mathrm{K}-$ $\mathrm{L}$ 分類は滕 $\mathrm{OA}$ の診断基準として諸外国におい ても広く用いられており，X線画像をもとに骨 棘の形成や関節裂隙の狭小化, 軟骨下骨の骨硬 化を基準として grade 0-4の 5 段階で評価する 方法である 19)。

中枢感作の評価として, QST のうち PPT と TSP を測定した。PPT はデジタルフォースゲー ジ (Algometer type II , SBMEDIC Electronics, Sweden)を用いて評価し, プローブ面積は $1 \mathrm{~cm}^{2}$, 加圧率は $30 \mathrm{kPa} / \mathrm{s}$ とし, 対象が疼痛を自覚し た際の加圧強度を測定した。測定部位は Arendt-Nielsen らの方法 ${ }^{1)}$ を参考に, 患側の 膝周囲 4 力所と下腿（前脛骨筋，脛骨粗面より 遠位 $5 \mathrm{~cm}$ ), 前腕 (長橈側手根伸筋, 上腕骨外 側上顆より遠位 $5 \mathrm{~cm}$ ) で測定した。膝関節の 測定部位は Knee 1：膝蓋骨内側端より内側 $3 \mathrm{~cm}$, Knee 2: 膝蓋骨下内側端より下方 $2 \mathrm{~cm}$, Knee 3: 膝蓋骨下外側端より下方 $2 \mathrm{~cm}$, Knee 4 : 膝蓋骨外側端より外側 $3 \mathrm{~cm}$ とし, これらの うち最低值部位の值を膝関節の PPT 测定值と した。TSP はPPT と同強度の圧刺激を 10 回 連続で刺激（刺激持続時間 1 秒，刺激間隔 1 秒） し, 10 回の疼痛強度を visual analogue scale (VAS) で測定した ${ }^{2}$ 。VAS は $0 \mathrm{~mm}$ を「疼痛な し」, $100 \mathrm{~mm}$ を「対象者が想像しうる耐え難い 
Table 1 Demographic and clinical data of each groups

\begin{tabular}{lccc}
\multicolumn{1}{c}{ Variable } & Group A & Group B & p value \\
\hline Number & 17 & 26 & n.s. \\
Age (years) & $67.1 \pm 12.2$ & $68.9 \pm 8.5$ & n.s. \\
Sex, Number (\%) & & & \\
Male & $2(12)$ & $10(38)$ & n.s. \\
Female & $15(88)$ & $16(62)$ & n.s. \\
BMI (kg/m ${ }^{2}$ ) & $25.4 \pm 3.7$ & $24.5 \pm 3.1$ & p $<0.001$ \\
Pain duration (months) & $63.5 \pm 60.3$ & $42.1 \pm 48.0$ & p $<0.001$ \\
Pain intensity (NRS) & $7.3 \pm 1.0$ & $3.3 \pm 1.3$ & $82.0 \pm 16.3$ \\
KOOS (function of daily living) & $60.5 \pm 16.6$ & & \\
\end{tabular}

Abbreviation: BMI, body mass index; NRS, numerical rating scale; KOOS, Knee injury and osteoarthritis outcome Score; n.s., not significant difference. The p value showed the result of Mann-Whitney U test and Fisher's exact test.

ほどの疼痛」とした。圧刺激中は刺激部位を一 定にするために，疼痛を生じない約 $10 \mathrm{kPa}$ の 圧を保持しながら，体表から離さず測定を行っ た。測定部位はPPT と同様，患側膝関節，下 腿，前腕で測定した。なお，膝関節の TSP は PPT 最低值部位で測定した。TSP は 1 回目の VAS 值で標準化した上で，10 回目の VAS 值を TSP の測定值と定義した ${ }^{10)}$ 。

\section{4. デー夕解析}

データは平均值および標準偏差を算出した。 患者特性, K-L 分類, QST 值の群間差は Mann-Whitney の U 検定および Fisher の直接 確率検定を，また，膝関節の疼痛と $\mathrm{K}-\mathrm{L}$ 分類， すべての QST 值の相関は Spearmanの順位相 関係数を用いて解析し，有意水準は $5 \%$ とした。

\section{結 果}

患者特性のうち年齢，性別，BMI，罹病期間
に群間差はなく，Group A が Group B と比較 し NRS は有意に高值 $(\mathrm{p}<0.001)$, KOOS は有 意に低值を示した $(\mathrm{p}<0.001)($ Table 1)。薬物療 法は, Group A が 71\%（12 名)，Group B 群が 23\%（6名）で処方されており，Group A が有 意に多かった $(\mathrm{p}<0.01)$ 。処方薬は，ロキソプ ロフェン (Group A：9 名, Group B：5名), セ レコキシブ (Group A：3名, Group B：1名), アセトアミノフェン (Group A：1名, Group $\mathrm{B} ： 0$ 名), デュロキセチン（Group A：2 名, Group B：0名）であった。

関節変形について, K-L 分類は grade 1 (5/11, Group A/Group B), $2(2 / 7), 3$ $(8 / 5) ， 4(2 / 3)$ で分布に差はなかった。

QST について, PPT は Group A で Group B と比較し膝関節 $(\mathrm{p}<0.001)$, 下腿 $(\mathrm{p}<0.01)$, 前 腕で低值を示した（p<0.001）(Fig.1)。TSP は Group A で Group B と比較し, 膝関節 $(\mathrm{p}<$ $0.001)$ ，下腿（p<0.001）で高值を示したが，前 腕で差はなかった（Fig.2）。 


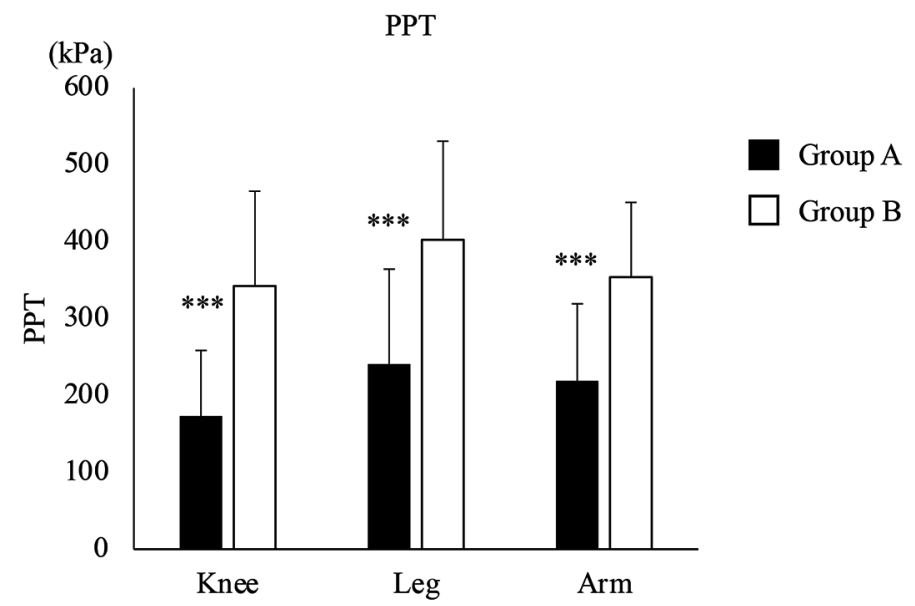

Fig.1 Difference of PPT (kPa; mean value \pm SD) at the most painful site of knee, tibialis anterior (Leg) and extensor carpi radialis longus (Arm).

Abbreviation: PPT, pressure pain threshold; Leg, tibialis anterior; Arm, extensor carpi radialis longus.

***, significantly difference compared group $\mathrm{B}(\mathrm{p}<0.001)$. The p value showed the result of Mann-Whitney $\mathrm{U}$ test. Group A has NRS $\geq 6$ and group B NRS $<6$.
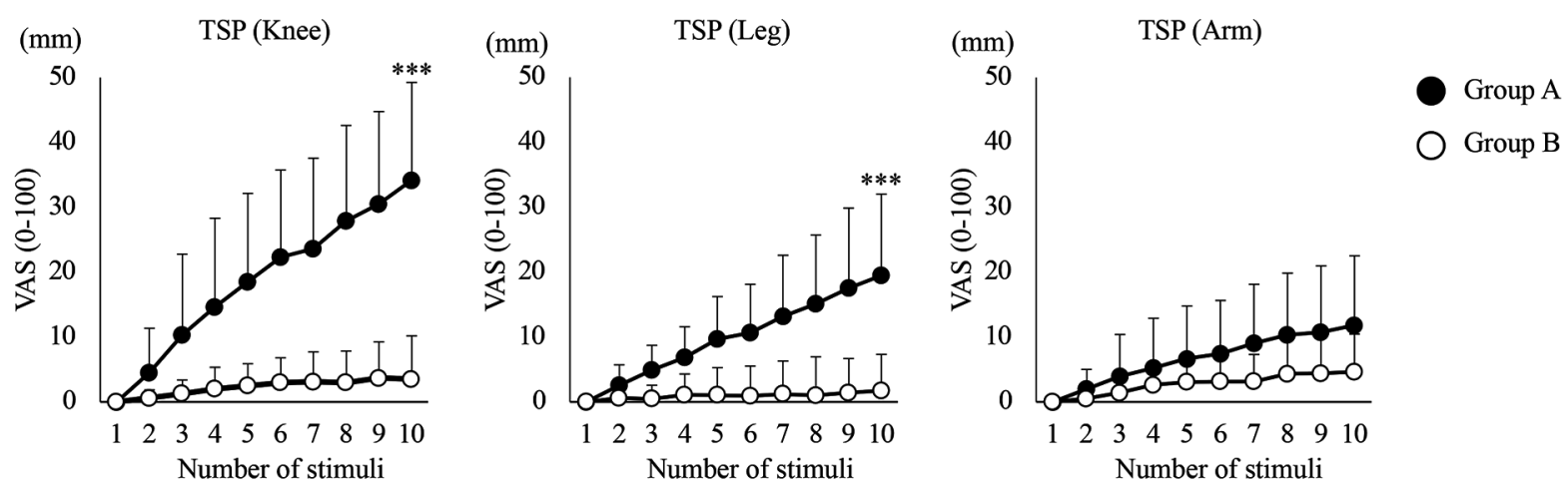

Fig.2 Difference of TSP at the most painful site of knee, tibialis anterior and extensor carpi radialis longus.

Abbreviation: TSP, temporal summation of pain; VAS, visual analogue scale; Leg, tibialis anterior; Arm, extensor carpi radialis longus.

***, significantly difference compared group B $(\mathrm{p}<0.001)$. The $\mathrm{p}$ value showed the result of Mann-Whitney $\mathrm{U}$ test. Group A has NRS $\geq 6$ and group B NRS $<6$.

\section{膝関節の疼痛 (NRS) と K-L 分類, QST 值} の相関は, NRS と K-L 分類の間に相関を認め なかった一方, PPT は膝関節 $(\mathrm{p}<0.01, \quad \mathrm{rs}=$ $-0.533)$ ，下腿 $(\mathrm{p}<0.01, \mathrm{rs}=-0.518)$, 前腕 $(\mathrm{p}<$ $0.01, \mathrm{rs}=-0.503)$ で負の相関，TSP は膝関節 $(\mathrm{p}<0.01, \quad \mathrm{rs}=0.762)$, 下腿 $(\mathrm{p}<0.01, \quad \mathrm{rs}=0.600)$ で正の相関を認めた (Table 2)。

\begin{tabular}{c}
\hline 考 察 \\
\hline 本研究で日本人膝 OA の中枢感作について \\
QST を用いて検討した結果, 疼痛症状の重篤 \\
な膝 OA では䍜患部である膝関節のみでなく, \\
下腿や前腕でも PPT の低下, 下腿の TSP の立 \\
進がみられ, 全身広範に痛覚感受性が立進し中 \\
枢感作を呈している可能性が示唆された。また,
\end{tabular}


Table 2 Correlations between NRS and K-L scale, PPT and TSP

\begin{tabular}{|c|c|c|}
\hline Variable & rs & $\mathrm{p}$ value \\
\hline K-L scale & 0.212 & n.s. \\
\hline \multicolumn{3}{|l|}{ PPT } \\
\hline Knee & -0.533 & $\mathrm{p}<0.01$ \\
\hline Leg & -0.518 & $\mathrm{p}<0.01$ \\
\hline Arm & -0.503 & $\mathrm{p}<0.01$ \\
\hline \multicolumn{3}{|l|}{ TSP } \\
\hline Knee & 0.762 & $\mathrm{p}<0.01$ \\
\hline Leg & 0.600 & $\mathrm{p}<0.01$ \\
\hline Arm & 0.215 & n.s. \\
\hline \multicolumn{3}{|c|}{$\begin{array}{l}\text { Abbreviation: NRS, numerical rating scale; K-L, } \\
\text { Kellgren-Lawrence scale; PPT, pressure pain thresh- } \\
\text { old; TSP, temporal summation of pain; n.s., not sig- } \\
\text { nificant difference. } \\
\text { Spearman's rank correlation coefficient (rs) and p } \\
\text { value showed in table. }\end{array}$} \\
\hline
\end{tabular}

膝 OA の慢性関節痛は K-L 分類と相関を認め なかった一方で，QST 值と有意な相関関係を 認めた。

膝 OA は, 関節裂隙の狭小化や軟骨下骨の 硬化，骨棘の形成などの関節構造変化に伴う疼 痛や機能障害を主症状とする疾患である。従来 から重篤な疼痛症状を有する者では重度の関節 変形を有することが数多く報告されており ${ }^{9)}$, 重度の OA 患者では TKA などの観血的治療に より高い除痛効果が得られる ${ }^{3)}$ 。TKAによっ て関節構造上の問題が解決されることで関節変 形に伴うアライメント異常が改善し, 関節構成 体へのメカニカルストレスが低減し疼痛の軽減 につながると考えられる。また，変形性関節症 に伴う痛みに対する関節内注射（関節ブロッ ク）は痛みを軽減させることが広く知られてい る 24)。さらに, 膝 OA に対する L5 神経ブロッ
クによる下肢全体の鎮痛効果 18) や，神経成長 因子 (nerve growth factor：NGF) 阻害薬である Tanezumabによって末梢感作を抑制すること で膝 $\mathrm{OA} の$ 疼痛を改善させる報告も増えてい る29)。したがって, 膝 OA の疼痛は関節変形 に伴う侵害受容性疼痛が基盤となっていること から，末梢組織ならびに末梢の侵害受容入力抑 制のアプローチは有効性の高い OA 治療戦略 であることはいうまでもない。しかしながら， 疼痛と関節変形が必ずしも関連しないといった 報告もあり 7,20)，臨床においても疼痛と関節変 形が乘離している症例を経験することは少なく ない。本研究の結果からも, Group A（NRS $\geq$ 6) と Group B $(\mathrm{NRS}<6)$ で K-L 分類に有意差 はなく, NRS と K-L 分類との相関も認められ なかったことから，滕 OAに打いてX 線画像 で評価される関節変形だけでは疼痛症状の重篤 化を説明しきれない場合があり，その他の要因 も膝 OA の疼痛に関与する可能性がうかがえる。

滕 OA の疼痛症状に影響を与えるその他の 要因として, 近年では中枢感作のような神経機 能異常が着目されている。特に，ヒトでは QST を用いて膝 OA 患者の中枢感作について 調べられており, 膝 OA 患者の $32 \%$ で膝関節

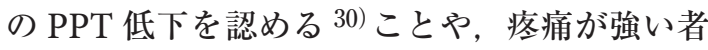
では罹患部や遠隔部における PPT 低下や TSP 充進を認めることが報告されている1)。これま での先行研究では, TKA 施行予定の関節変形 の重篤な膝 OA 患者 (K-L 分類 grade 3-4) に 対象を限定して検討がなされてきたため, 本研 究では K-L 分類 grade 1-2 の関節変形が軽度 な患者も対象に含めて検討を行った。その結果, これまでに報告されてきた関節変形が重度の膝 $\mathrm{OA}$ だけでなく, 関節変形が軽度の滕 $\mathrm{OA}$ を含 めた場合でも，PPT 低下と TSP 光進がみられ， さらにそれらは疼痛症状と有意に相関した。こ 
れらのことから, 日本人膝 $\mathrm{OA}$ では, $\mathrm{X}$ 線画像 で評価される関節変形の程度だけでなく中枢感 作のような神経機能異常も慢性関節痛に影響を 及ぼす可能性がある。加えて, 本研究では PPT 低下, TSP 充進が罹患部の膝関節のみならず, 下腿や前腕といった遠隔部にまで及んでいた。 特に Dynamic QST である TSP は脊髄後角にお ける Wind-up 現象を反映する評価であるが5), 機能的磁気共鳴画像法 (functional magnetic resonance imaging：fMRI）を用いた先行研究に おいては，TSP 充進は吻側延髄腹内側部や中脳 水道周囲灰白質などの下行性疼痛抑制系に関わ る脳幹領域との関連が報告されている2)。また, 感作現象は隣接する脊髄分節へと広がる可能性 が示唆されており 14,15), 慢性腰痛や線維筋痛症, TKA 後の遷延性疼痛などでも罹患部位とは離 れた遠隔部にまで及ぶ広範性痛覚過敏を呈して いることが報告されている ${ }^{6,22,27) 。 こ れ ら の こ ~}$ とより, 膝 OAに打いても他の慢性疼痛疾患と 同様，疼痛症状が強い症例では中枢性疼痛調節 機能が変調し, 痛覚過敏が広範囲に広がる中枢 感作を呈している可能性が考えられる。

以上のように，今回の日本人膝 $\mathrm{OA}$ 患者の QST 検証によって, X 線画像で評価される関 節変形の程度に加え, 中枢感作のような神経系 の要因も疼痛の重篤化に関与する可能性が示唆 された。今回の結果は, 本邦の膝 $\mathrm{OA}$ の病態解 析において, 中枢感作が重要な疼痛関連要因の ひとつとなりうることを示唆するものである。

本研究にはいくつかの限界がある。本研究は 横断的調查であり, 中枢感作が疼痛の軽減・維 持・増悪といった改善パターンに関与するか, 治療による疼痛軽減に伴い中枢感作にも変化が 生じるかについては不明である。また，本研究 の疼痛症状の強い膝 $\mathrm{OA}$ 患者は, 中枢感作と ともに末梢感作も呈しており, X 線画像検查で
は検出できない末梢組織の問題が存在していた 可能性がある。近年, 滕 OA の末梢組織の問 題として, 軟骨下骨の骨髄病変である bone marrow lesions (BML) が疼痛や病期進行に関 わることが明らかとなってきている 13)。BML は軟骨下骨の微小骨折や局所的な骨代謝回転の 克進を示しており，X線画像で関節変形重症度 が軽度であっても，BMLを認める膝 $\mathrm{OA}$ 患者 が存在する11)。よって今後はMRIを用いた画 像評価なども加えた病態解析を追加して検討す る必要がある。さらに, 薬物療法については, 疼痛が重篤な膝 OA 患者の方が薬物療法を併 用している者が多かったことから, 疼痛コント ロールが不良であった可能性が考えられる。薬 物療法の有無や処方されている薬剤は交絡因子 となる可能性があり, サンプルサイズを増やし, さらなる検討が必要である。

\section{結語}

本邦の膝 OA において, 膝関節の主観的疼 痛は, $\mathrm{X}$ 線画像で評価される関節変形の程度と の関連は低い一方, 中枢感作の程度と関連する ことが示唆された。また，自覚的な疼痛の強い 膝 $\mathrm{OA}$ 患者ほど膝関節のみならず遠隔部にま で痛覚過敏が及んでおり, 中枢感作が症状を重 篤化する可能性がうかがえた。

\section{文 献}

1) Arendt-Nielsen, L., Nie, H., Laursen, M.B., Laursen, B.S., Madeleine, P., Simonsen, O.H., Graven-Nielsen, T., Sensitization in patients with painful knee osteoarthritis, Pain, 149 (2010) 573-581.

2) Bosma, R.L., Ameli Mojarad, E., Leung, L., Pukall, C., Staud, R., Stroman, P.W., Neural correlates of temporal summation of second pain in human brainstem and spinal cord, Hum. Brain Mapp., 36 (2015) 5038-5050. 
3) Chesworth, B.M., Mahomed, N.N., Bourne, R.B., Davis, A.M., Willingness to go through surgery again validated the WOMAC clinically important difference from THR/TKR surgery, J. Clin. Epidemiol., 61 (2008) 907-918.

4) Collins, S.L., Moore, R.A., McQuay, H.J., The visual analogue pain intensity scale: what is moderate pain in millimetres?, Pain, 72 (1997) 95-97.

5) Craig, A.D., Andrew, D., Response of spinothalamic lamina I neurons to repeated brief contact heat stimulation in the cat, J. Neurophysiol., 87 (2002) 1902-1914.

6) den Bandt, H.L., Paulis, W.D., Beckwée, D., Ickmans, K., Nijs, L., Voogt, L., Pain mechanisms in low back pain: a systematic review with meta-analysis of mechanical quantitative sensory testing outcomes in people with nonspecific low back pain, J. Orthop. Sports. Phys. Ther., 49 (2019) 698-715.

7) Dieppe, P.A., Lohmander, L.S., Pathogenesis and management of pain in osteoarthritis, Lancet, 365 (2005) 965-973.

8) Djahani, O., Rainer, S., Pietsch, M., Hofmann, S., Systematic analysis of painful total knee prosthesis, a diagnostic algorithm, Arch. Bone Jt. Surg., 1 (2013) 48-52.

9) Duncan, R., Peat, G., Thomas, E., Hay, E., McCall, I., Croft, P., Symptoms and radiographic osteoarthritis: not as discordant as they are made out to be?, Ann. Rheum. Dis., 66 (2007) 86-91.

10) Edwards, R.R., Mensing, G., Cahalan, C., Greenbaum, S., Narang, S., Belfer, I., Schreiber, K.L., Campbell, C., Wasan, A.D., Jamison, R.N., Alteration in pain modulation in women with persistent pain after lumpectomy: influence of catastrophizing, J. Pain Symptom. Manage., 46 (2013) 30-42.

11) Elder, GJ., From marrow oedema to osteonecrosis: common paths in the development of posttransplant bone pain, Nephrology (Carlton), 11 (2006) 560-567.

12) Felson, D.T., The sources of pain in knee osteoarthritis, Curr. Opin. Rheumatol., 17 (2005) 624-628.

13) Felson, DT., Niu, J., Guermazi, A., Roemer, F., Aliabadi, P., Clancy, M., Torner, J., Lewis, CE., Nevitt, MC., Correlation of the development of knee pain with enlarging bone marrow lesions on magnetic resonance imaging, Arthritis Rheum., 56 (2007) 2986-2992.

14) Hoheisel, U., Mense, S., Response behaviour of cat dorsal horn neurones receiving input from skeletal muscle and other deep somatic tissues, J. Physiol., 426 (1990) 265-280.

15) Hoheisel, U., Mense, S., Simons, D.G., Yu, X.M., Appearance of new receptive fields in rat dorsal horn neurons following noxious stimulation of skeletal muscle: a model for referral of muscle pain?, Neurosci. Lett., 153 (1993) 9-12.

16) Imamura, M., Imamura, S.T., Kaziyama, H.H., Targino, R.A., Hsing, W.T., de, Souza, L.P., Cutait, M.M., Fregni, F., Camanho, G.L., Impact of nervous system hyperalgesia on pain, disability, and quality of life in patients with knee osteoarthritis: a controlled analysis, Arthritis Rheum., 59 (2008) 1424-1431.

17) Jensen, M.P., Mardekian, J., Lakshminarayanan, M., Boye, M.E., Validity of 24-h recall ratings of pain severity: biasing effects of "Peak" and "End" pain, Pain, 137 (2008) 422-427.

18) Kawada, T., Ushida, T., Ikeucho, M., Kawakami, T., Yamanaka, N., Ikemoto, T., Tani, T., Komatsu, M., Clinical study of hip joint referred pain, PAIN RESEARCH, 21 (2006) 127-132.

19) Kellgren, J., Lawrence, J., Radiologic assessment of osteoarthritis, Ann. Rheum. Dis., 16 (1957) 494-501.

20) Muraki, S., Oka, H., Akune, T., Mabuchi, A., Enyo, Y., Yoshida, M., Saika, A., Suzuki, T., Yoshida, H., Ishibashi, H., Yamamoto, S., Nakamura, K., Kawaguchi, H., Yoshimura, H., Prevalence of radiographic knee osteoarthritis and its association with knee pain in the elderly of Japanese population-based cohorts: the ROAD study, Osteoarthritis Cartilage, 17 (2009) 1137-1143.

21) Nakamura, N., Takeuchi, R., Sawaguchi, T., Ishikawa, H., Saito, T., Goldhahn, S., Cross-cultural adaptation and validation of the Japanese Knee Injury and Osteoarthritis Outcome Score (KOOS), J. Orthop. Sci., 16 (2011) 516-523.

22) O’Brien, A.T., Deitos, A., Triñanes, Pego, Y., Fregni, F., Carrillo-de-la-Peña, MT., Defective Endogenous Pain Modulation in Fibromyalgia: A Meta-Analysis of Temporal Summation and Conditioned Pain Modulation Paradigms, J. Pain, 19 (2018) 819-836.

23) Peat, G., McCarney, R., Croft, P., Knee pain and osteoarthritis in older adults: a review of community burden and current use of primary health care, Ann. Rheum. Dis., 60 (2001) 9197.

24) Qvistgaard, E., Christensen, R., Torp-Pedersen, S., Bliddal, H., Intra-articular treatment of hip osteoarthritis: a randomized trial of hyaluronic acid, corticosteroid, and isotonic saline, Osteoarthritis Cartilage, 14 (2006) 163-170. 
25) Roos, E.M., Lohmander, L.S., The Knee injury and Osteoarthritis Outcome Score (KOOS): from joint injury to osteoarthritis, Health Qual. Life Outcomes, 1 (2003) 64.

26) Sharma, L., Kapoor, D., Issa, S., Epidemiology of osteoarthritis: an update, Curr. Opin. Rheumatol., 18 (2006) 147-156.

27) Skou, S.T., Graven-Nielsen, T., Rasmussen, S., Simonsen, O.H., Laursen, M.B., ArendtNielsen, L., Widespread sensitization in patients with chronic pain after revision total knee arthroplasty, Pain, 154 (2013) 1588-1594.

28) Suokas, A.K., Walsh, D.A., McWilliams, D.F., Condon, L., Moreton, B., Wylde, V., ArendtNielsen, L., Zhang, W., Quantitative sensory testing in painful osteoarthritis: a systematic review and meta-analysis, Osteoarthritis Cartilage, 20 (2012) 1075-1085.
29) Lane, N.E., Schnitzer, T.J., Birbara, C.A., Mokhtarani, M., Shelton, D.L., Smith, M.D., Brown, M.T., Tanezumab for the treatment of pain from osteoarthritis of the knee, N. Engl. J. Med., 363 (2010) 1521-1531.

30) Wylde, W., Palmer, S., Learmonth, L.D., Dieppe, P., Somatosensory abnormalities in knee OA, Rheumatology, 51 (2012) 535-545.

Address for correspondence: Takafumi Hattori Kobe Gakuin University

Graduate School of Rehabilitation

518 Arise, Ikawadani-cho, Nishi-ku, Kobe, Hyogo 651-2180, Japan 